\title{
NEW SAWFLIES FROM SPAIN (HYMENOPTERA, TENTHREDINIDAE)
}

\author{
A. Haris*
}

\begin{abstract}
Dolerus varispinus Hartig, 1837; Nematus respondens Förster, 1854; Pristiphora kamtchatica Malaise, 1931 and Pristiphora nievesi sp. n. are recorded from Spain for the first time. The description of Pristiphora nievesi sp. n. is given and compared to P. subbifida (Thomson, 1871); P. carpentieri Konow, 1903 and P. parnasia Konow, 1902.
\end{abstract}

Key words: Hymenoptera, Tenthredinidae, new species, new records, Spain.

\section{RESUMEN}

Nuevas avispas porta-sierra de España (Hymenoptera, Tenthredinidae)

Las especies Dolerus varispinus Hartig, 1837; Nematus respondens Förster, 1854 y Pristiphora kamtchatica Malaise, 1931 se citan por primera vez en España. Se describe Pristiphora nievesi sp. n. y se compara con P. subbifida (Thomson, 1871); P. carpentieri Konow, 1903 y P. parnasia Konow, 1902.

Key words: Hymenoptera, Tenthredinidae, nueva especie, nuevas citas, España.

\section{Introduction}

In February 2004, the author studied the sawfly material of the Museo Nacional de Ciencias Naturales, Madrid under the grant of a BIODIBERIA project. Two subfamilies of the real sawflies (Tenthredinidae) were selected to process, namely Nematinae and Dolerinae.

According to the interpretation of Zombori, (1982), the subfamily Nematinae, consisting mainly of small sawflies, $3.0-7.0 \mathrm{~mm}$, is characterised by a complete radial cell, which is not divided by a radial cross vein. Their cuticle is weekly sclerotised, soft. The Nematinae fauna is poor in the Mediterranean region, reaching its greatest diversity in the Scandinavian and Siberian regions.

The characteristic feature of the subfamily Dolerinae is the missing 2nd cubital cross-vein resulting in a very elongated second cubital cell.
Medium sized, 7.0-12.0 mm, black or red-andblack species.

The first check-list of Spanish sawflies was published by Ceballos, (1956). Liston also referred to Spanish sawflies in the Compendium of European Sawflies in 1995. He enumerated 245 sawfly species from Spain which is relatively poor compared to northern countries. On the other hand, the Iberian peninsula is rich in endemic species. 32 species (including the new species described in this paper) are known to occur only in the Iberian Peninsula.

\section{Matherial and Methods}

Approximately 600 specimens of subfamilies Dolerinae and Nematinae were identified. For the identification of Nematinae, the most useful and

* Petöfi str. 103, H-81242, Urhida, Hungary. 
comprehensive handbook is that written by Zhelochovtsev (1988) which includes about $95 \%$ of the total European fauna. For the identification of the Dolerinae fauna, papers by Llorente (1988), Haris (2000) and the revision of Blank and Taeger (1992) were used. The genitalia dissection and study, especially in males, is inevitable in these groups. The necessary genitalia figures are available in the above mentioned papers. The sawsheath structure of females is clearly visible without any dissection. The saw preparation can easily destroy specimens, and was therefore not used. The following features were studied during the identification process: colour, sawsheath-structure, penis valve-structure, surface sculpture, teeth of claws and relative ratios of the body.

\section{Results}

\section{Dolerinae}

Dolerus varispinus Hartig, 1837

España. No further data available. One male was collected. Sporadic European species, new record for Spain.

\section{Nematinae}

Nematus respondens Förster, 1854

El Ventorillo, 1480 m, Madrid, 01-30. 06. 1989. Four males were collected. Known from Northern and Central Europe. Sporadic species. New record for Spain.

Pristiphora kamtchatica Malaise, 1931

El Ventorillo, 1480 m, Madrid, 09-23. 06. 1990. Six females were collected. Widely distributed Holarctic species. Rare. New record for Spain.

\section{Pristiphora nievesi sp. $\mathrm{n}$.}

(Figs. 1, 2 and 3)

Holotype: female: "El Ventorillo, 1480 m, Madrid, Malaise trap, 11-20. 04. 1990, Nieves and Rey leg."

PARATYPes: female: "El Ventorillo, $1480 \mathrm{~m}$, Madrid, Malaise trap, 7-15. 05. 1990, Nieves and Rey leg."; female: "El Ventorillo, 1480 m, Madrid, Malaise trap, 23-31. 05. 1990, Nieves and Rey leg."; female: "El Ventorillo, 1480 m, Madrid, Malaise trap, 22-30. 04. 1990, Nieves and Rey leg."

Holotype and paratypes are deposited in the Natural History Museum, Madrid (Museo Nacional de Ciencias Naturales).

DESCRIPTION. Head and thorax entirely black including antennae and mouthparts, only cenchri white (Fig. 3). Abdomen yellow (Fig. 3) but basal 2/3
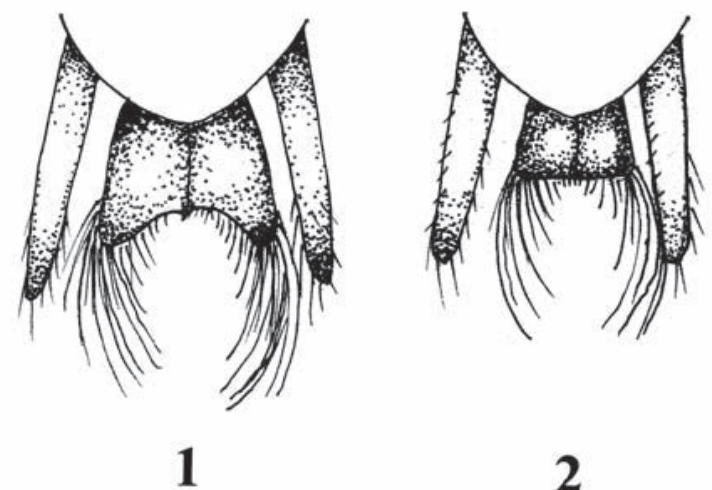

Figs. 1-2. - Sawsheath in dorsal view of Pristiphora subbifida (Thomson, 1871) (1) and of Pristiphora nievesi (2).

Figs. 1-2.- Vista dorsal del estuche del taladro del ovipositor de Pristiphora subbifida (Thomson, 1871) (1) y de Pristiphora nievesi (2).

of first tergite and apex of sawsheath black. Legs yellow, black: fore coxae, strips on fore and middle femora, narrow apices of middle and wide apices of hind tibiae and hind tarsi. Wings subhyaline, venation and stigma dark brown. Colour variations: hardly visible brownish yellow spots may occur at the hind corner of eyes, hind tibiae may be dominantly black. OOL : POL : OCL: $9: 14: 8$. Ratios of the antennal segments: $6: 5: 24: 22: 22: 16: 12: 12: 14$. Length of hind tarsus : length of inner hind tibial spur: $7: 3$. Head shiny with sporadic punctures on the temples and on the postocellar area. Frontal area densely and finely punctured. Mesonotal lobes shiny, moderately deeply and moderately densely punctured. Mesoscutellum moderately deeply and moderately sparsely punctured, shiny. Mesoscutellar appendage densely but not uniformly punctured, moderately shiny. Postscutellum shiny, hardly punctured. Mesopleuron mostly shiny and hardly punctured but frontally moderately punctured. Clypeus subtruncate, very slightly emarginated. Frontal area well outlined. Claws with long inner tooth. Sawsheath truncate (Fig. 2), dilated with long apical hairs. Cerci long, longer than sawsheath. Length: 4.0-5.0 mm.

ETYMOLOGY. This species is named in honour of Dr. José Luis Nieves Aldrey, the leader of the El Ventorrillo expedition where the new species is captured (subs.).

Comments. The new species is related to Pristiphora subbifida (Thomson, 1871); P. carpen- 


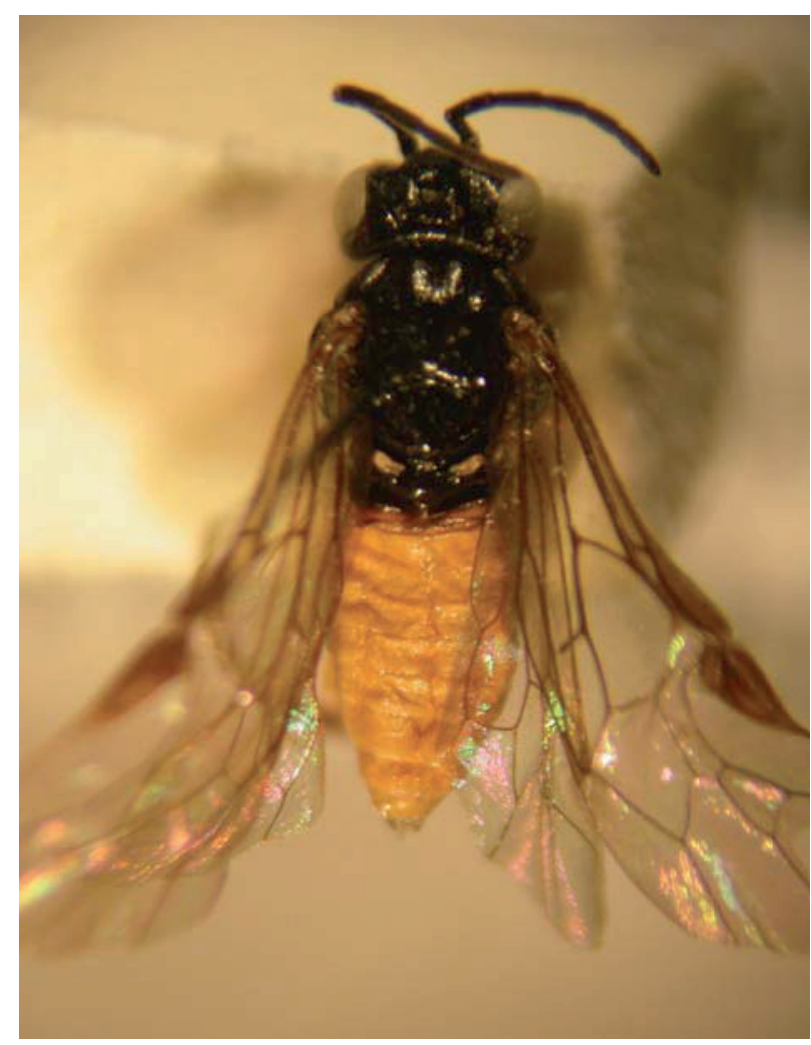

Fig. 3.- Pristiphora nievesi sp. n. holotype.

Fig. 3.- Pristiphora nievesi sp. n. holotipo.

tieri Konow, 1903 and P. parnasia Konow, 1902. All of these species have bifid or subbifid claws which is a very special feature of the genus. Abdomen extensively or entirely yellow above and beneath. Most of them are richly coloured with yellow on the mesopleuron or if the mesopleuron is black at least their pronotum -partly-, tegulae and orbits are yellow, except in the new species, which has an entirely black thorax and head. All of them have a deeply emarginated sawsheath (Fig. 1) except the new species in which the sawsheath is truncate, subtruncate apically (Fig. 2). For a comparison of females see in the key below.

\section{Key of females of Pristiphora subbifida group}

Pristiphora subbifida group: claws always bifid, subbifid, abdomen yellow above and beneath, sometimes black spots may occur on the tergites. Hind legs are at least partly light coloured. Stigma black or dark brown.
1. Mesopleuron yellow or black with yellow spot .............. 2

- Mesopleuron entirely black. Mouthparts, orbits, thorax entirely black, sawsheath truncate (subtruncate). The smallest species of the group. 4.0-5.0 mm .... P. nievesi sp. n.

2. Mesopleuron and orbits entirely yellow. $4.5-7.0 \mathrm{~mm}$ P. subbifida (Thomson, 1871)

- Mesopleuron partly black, orbits entirely black .............. 3

3. Abdominal tergites $1-3$ and 7-8 with black spots (these spots may absent from tergites 3 and 7). $5.0 \mathrm{~mm}$

P. carpentieri Konow , 1903

- Abdomen yellow, only first tergite black. $6.0 \mathrm{~mm}$............. P. parnasia Konow, 1902

\section{ACKNOWLEDGEMENTS}

I wish to express my grateful thanks to Dr. Carolina Martín and Dr. Jose Luis Nieves Aldrey for their support of my work.

\section{References}

Blank, S. M. \& Taeger, A., 1992. Die von Th. Hartig und A. Förster in der Gattung Dolerus bechriebenen Arten. Zeitschrift für Entomologie, 13(12): 213-224.

Ceballos, G., 1956. Catalogo de los Himenopteros de Espana. Trabajos del Instituto Español de Entomología. Madrid. 554 pp.

HARIS, A., 2000. Study on the Palaearctic Dolerus Panzer, 1801 species (Hymenoptera: Tenthredinidae). Folia entomologica hungarica, 61:95-148.

Liston, A. D., 1995. Compendium of European Sawflies. Chalastos Forestry. Gottfrieding. 190 pp.

Llorente Vigil, G., 1988. El genero Dolerus Panzer, 1801 (Hymenoptera, Tenthredinidae) en España. III. Congreso Ibérico de Entomología, Granada: 349360.

Zhelochovtsev, A. N., 1988. Pereponcatokrylye. Opredelitel nasekomych evropejskos casti SSSR, 3(6): 1267.

Zombori, L., 1982. Levéldarázs-alkatúak II. Tenthredinoidea II. Fauna Hungariae 153. Akadémiai Kiadó. Budapest. 144 pp. 